\title{
STUDI HYGIENE SANITASI DAN KANDUNGAN BAKTERI Salmonella sp PADA PENGOLAHAN SATE AYAM DI DESA PASIR LOR KECAMATAN KARANGLEWAS KABUPATEN BANYUMAS TAHUN 2017
}

\author{
Indah Sri Lestari*), Asep Tata Gunawan**) \\ Jurusan Kesehatan Lingkungan, Politeknik Kesehatan Kemenkes Semarang, \\ Jl.Raya Baturaden KM 12 Purwokerto, Indonesia
}

\begin{abstract}
Abstrak
Makanan tidak hanya harus memenuhi gizi dan mempunyai bentuk yang menarik, tetapi juga harus bebas dari mikroorganisme dan bahan-bahan kimia yang dapat menyebabkan penyakit. Salah satu akibat dari penyediaan makanan dan minuman yang tidak memenuhi syarat kesehatan adalah keracunan makanan. Tujuan penelitian ini adalah untuk mendeskripsikan hygiene sanitasi dan kandungan bakteri Salmonella sp pada sate ayam di Desa Pasir Lor Kecamatan Karanglewas Kabupaten Banyumas Tahun 2017. Metode penelitian yang digunakan adalah metode deskriptif yang menggambarkan hygiene sanitasi dan kandungan bakteri Salmonella sp pada sate ayam. Pengumpulan data diperoleh melalui observasi menggunakan checklist dan pemeriksaan Salmonella sp pada sate ayam di laboratorium. Berdasarkan hasil penelitian diperoleh hygiene sanitasi pengolahan sate ayam pada 4 pedagang mulai dari penjamah, sanitasi alat, sanitasi tempat pengolahan dan penyimpanan bahan makanan dikategorikan tidak memenuhi syarat. Sedangkan bahan makanan, cara pemilihan bahan makanan, pengolahan makanan dan penyajian makanan dikategorikan memenuhi syarat. Berdasarkan pemeriksaan sampel dari 4 pedagang di laboratorium, 4 sampel sate ayam mentah 3 positif Samonella sp dan 4 sampel sate matang keempat sampel tersebut negatif Salmonella sp. Kesimpulan dari hasil penelitian ini adalah hygiene sanitasi pengolahan sate ayam di 4 pedagang masih ada yang belum memenuhi syarat, serta dalam 4 sampel sate ayam matang negatif Salmonella sp. Saran yag dapat diberikan yaitu sebaiknya pedagang atau pemilik memeperbaiki hygiene saitasi pengolahan makanan yang belum memenuhi syarat pengolahan makanan yang baik dan benar
\end{abstract}

Kata kunci:pengolahan makanan; Salmonella sp;sate ayam; kesehatan lingkungan

\begin{abstract}
[Study Of Hygiene Sanitation And Bacteria Content Of Salmonella sp On Sate Ayam Processing In Pasir Lor Village Karanglewas Subdistrict Banyumas Regency Year Of 2017] Food must not only meet the nutrients and have an attractive shape, but also must be free of microorganisms and chemicals that can cause disease. One of the effects of providing food and beverages that do not meet health requirements is food poisoning. The purpose of this study was to describe sanitation hygiene and bacterial content of Salmonella sp on sate ayam in Pasir Lor village, Karanglewas sub-district, Banyumas regency, 2017. The research method used is descriptive method to describe sanitation hygiene and bacteria content of Salmonella sp on sate ayam. Data collection was obtained through observation using checklist and examination of Salmonella sp on chicken sate. The results of the research obtained hygiene sanitation processing sate ayam at 4 seller from handlers, sanitation tools, sanitization places processing and storage of food items are categorized as not meet the regulations. While foodstuffs, food selection, food processing and food presentation are categorized as regulations. Based on the examination of sate ayam samples in the laboratory, 3 samples of raw sate ayam is positive Samonella sp and 4 samples of mature sate ayam is negative Salmonella sp. The conclusion of this research is hygiene sanitation processing of sate ayam in 4 selles still have not meet regulation, and all of sample was negative Salmonella sp on mature sate ayam. Therefore, the researchers suggest to selles or owners should improve hygiene sanitation food processing as properly and correctly.
\end{abstract}

Keywords: Food processing, Salmonella sp., Sate ayam, Environmental Health 
1. Pendahuluan: UU No. 36 Tahun 2009 tentang Kesehatan Bagian ke XVI Bab VI Pasal 109112 mengatur pokok-pokok pengamanan makanan dan minuman. Makanan tidak hanya harus memenuhi gizi dan mempunyai bentuk yang menarik, tetapi juga harus bebas dari mikroorganisme dan bahan-bahan kimia yang dapat menyebabkan penyakit .

Makanan dan minuman seringkali menjadi penyebab timbulnya berbagai macam penyakit. Makanan atau minuman yang tercemar akan menjadi media yang baik bagi pertumbuhan mikroorganisme (bakteri). Bakteri yang sering dijumpai pada makanan dan minuman tercemar salah satunya adalah Salmonella $s p$. Pada umumnya infeksi Salmonella sp menyebabkan penyakit salmonellosis (penyebab: Salmonella choleraesuis dan Salmonella enteriditis) dengan ditandai gejala mual, muntah sakit kepala, sakit perut, diare hebat dan penyakit demam typhoid (penyebab: Salmonella typhi) yang memiliki gejala demam yang berkelanjutan, disertai sakit kepala, tidak nafsu makan, dengn bercakbercak kemerahan ditubuh, sedikit batuk , susah buang air besar, gejala panas berlanjut sampai dua minggu (bila tidak diobati), dinding usus mengalami perlukaan dan menjadi sangat tipis, sehingga terjadi jebolnya dinding usus. (Dirjen PP \& PL Depkes RI 2010)

Salah satu akibat dari penyediaan makanan dan minuman yang tidak memenuhi syarat kesehatan adalah keracunan makanan. Kasus keracunan makanan adalah termasuk masalah serius tidak memilih orang, tempat dan waktu dapat menyerang siapa saja, dimana saja, kapan saja, mulai dari anak-anak hingga lansia. Kasus keracunan makanan menduduki urutan penyebab kejadian luar biasa (KLB) kedua di Jawa Tengah yang menyerang 63 desa di 53 kecamatan dengan penderita sebanyak 1.298 orang dengan CFR sebesar 0,46\%. Pada tahun 2004, dari 35 kabupaten/kota yang ada di Jawa Tengah terdapat 22 kabupaten/kota yang melaporkan adanya KLB keracunan makanan. Kota Semarang, Kabupaten Boyolali, Cilacap, Banyumas, dan Purbalingga merupakan wilayah yang banyak ditemukan KLB keracunan makanan. (http://www.dinkesjatengprov.go.id/dokumen/profil/prof ile2004/bab4.htm).

Pada kasus yang terjadi tanggal 13 Desember 2012 di desa Lubuk Godang Kecamatan Koto Balingka Kabupaten Pasaman Barat, Sumatera Barat, ada 40 korban keracunan sate yang dirawat di Puskesmas Ujung Gading. Keracunan mulai dari kalangan dewasa dan anak-anak itu diduga karena memakan sate dari salah satu pedagang sate keliling yang melintas didaerah setempat, semua korban mengalami pusing, mual dan muntah. Setelah pengujian sampel, ternyata sate tersebut mengandung bakteri Salmonella $s p$ (http://regional.kompas.com/read/2012/12/13/08505129/ mediasiber.html).

Pada Rabu , 7 Mei 2014 terjadi kasus keracunan makanan yang menimpa 5 warga Dusun Kampung Tinggi, Desa Rokan Koto Ruang, Kecamatan Rokan IV Koto, Kabupaten Riau, mengalami keracunan setelah menyantap makanan sate ayam korban mengalami pusing, mual dan muntah secara terus menerus (http://m.riaupos.co/48216-berita-5-warga-rokan-hulukeracunan-sate.html).

Selain itu, penelitian yang pernah dilakukan oleh Damaris Adolfina Tefa tentang Studi Kandungan Salmonella Pada Daging Ayam Segar Yang Dijual di Pasar Sarimulyo Purwokerto Timur Tahun 2006 menyatakan bahwa 8 sampel daging ayam segar 100\% positif mengandung Salmonella (Damaris Adolfina Tefa, 2006, h. iii).

Sate ayam termasuk dalam makanan jajanan karena sate ayam diolah di tempat penjualan atau disajikan sebagai makanan siap santap untuk dijual bagi umum dan menjadi makanan kegemaran bagi sebagian keluarga. Konsumsi sate ayam merupakan salah satu indikasi tingginya kesadaran masyarakat akan kebutuhan protein hewani. Biasanya sate ayam Madura disajikan tanpa pemasakan terlebih dahulu sebelum dibakar sehingga dimungkinkan bakteri dengan mudah menggunakan sate tersebut sebagai media pertumbuhan. Masakan yang kurang matang dapat terjadi bila memasak daging berukuran besar karena ukurannya itu menambah masalah penetrasi panas yang cukup. Tanpa penggunaan suhu yang cukup tinggi dan cukup lama, mikroorganisme tidak terbunuh atau racun yang tahan panas tidak termusnahkan (Koes Irianto, 2006, h. 90).

Salmonellosis menyebabkan gastroenteristis (gangguan saluran pencernaan akut), penyebabnya adalah Salmonella choleraesuis dan Salmonella enteriditis. Salmonellosis terjadi setelah waktu inkubasi 6-72 jam (rata-rata 24-48 jam). Setelah memakan makanan yang mengandung Salmonella. Gejala awal yang ditimbulkan berupa kelelahan, nyeri perut bagian atas , diare, mual-mual, dan sakit kepala dan demam lebih dari 37,8 ${ }^{0}$ C. (Arisman, 2009, h.76)

Sate ayam yang berada di Desa Pasir Lor Kecamatan Karanglewas Kabupaten Banyumas merupakan jenis sate ayam yang tidak melalui proses pengolahan sebelum dipanggang. Tujuan dari penulisan kajian ini yaitu mendeskripsikan hygiene sanitasi dan kandungan bakteri Salmonella sp pada pengolahan sate ayam di Desa Pasir Lor Kecamatan Karanglewas Kabupaten Banyumas Tahun 2017

2. Bahan dan Metode: Bahan utama yang digunakan pada penelitian ini yaitu sate ayam sebelum dan setelah dipanggang dari 4 pedagang sate ayam di Desa Pasir Lor Kecamatan Karanglewas Kabupaten Banyumas. Pengumpulan data pada penelitian ini dengan cara:

a. Observasi

Observasi yaitu pengumpulan data yang dilakukan dengan cara pengamatan dan pencatatan langsung secara nyata di lapangan, pengamatan mengenai penjamah, bahan makanan, sanitasi alat, tempat pengolahan, pemilihan bahan makanan, penyimpanan bahan makanan, pengolahan sate, dan penyajian sate. Memenuhi syarat bila semua syarat 
dapat mengkontaminasi makanan apabila tidak mencuci tangan atau menggunakan sarung tangan pada saat mengolah makanan karena kuku yang tidak bersih dan panjang dapat menjadi tempat berkembangnya bakteri. Menurut Keputusan Menteri Kesehatan RI No. 942/MENKES/SK/VII/2003 Tentang Persyaratan Higiene Sanitasi Makanan Jajanan, personal hygiene yang baik salah satunya yaitu kuku penjamah dalam keadaan bersih. Seharusnya pedagang menegur penjamahnya apabila keadaan kuku tidak bersih dan penjamah memotong kuku minimal satu minggu sekali untuk menghindari kuku tidak bersih dan panjang yang dapat menjadi tempat berkembangnya bakteri serta selalu membersihkan kuku pada saat mencuci tangan.

b. Mencuci Tangan Sebelum Mengolah Makanan

Pada penjamah Mr. A dan Mr. B sebelum mengolah makanan tidak mencuci tangan terlebih dahulu. Tangan yang kotor akibat tidak mencuci tangan sebelum mengolah makanan dapat mengkontaminasi makanan dan merugikan konsumen. Menurut Keputusan Menteri Kesehatan RI No. 942/MENKES/SK/VII/2003 Tentang Persyaratan Higiene Sanitasi Makanan Jajanan, personal hygiene yang baik salah satunya yaitu mencuci tangan sebelum mengolah makanan. Seharusnya pedagang menegur penjamahnya apabila tidak mencuci tangan sebelum mengolah makanan, menggunakan sarung tangan pada saat mengolah makanan dan mencuci tangan yang baik dan benar dengan sabun dan air mengalir. Selain itu perlu dilakukan penyuluhan oleh petugas puskesmas atau dinas kesehatan setempat terhadap pedagang dan panjamah mengenai personal hygiene cara mencuci tangan dengan baik dan benar dalam bentuk poster atau stiker.

\section{c. Memakai Celemek}

Dari 4 lokasi pada 4 pedagang sate ayam semua tidak memakai celemek. Salah satu fungsi celemek yaitu sebagai alat pelindung diri (APD) penjamah apabila dalam mengolah makanan terjadi kecelakan kerja, alat pelindung diri lainnya seperti seperti penutup kepala, sarung tangan dan pakaian kerja. Menurut Keputusan Menteri Kesehatan RI No. 942/MENKES/SK/VII/2003 Tentang Persyaratan Higiene Sanitasi Makanan Jajanan, personal hygiene yang baik salah satunya memakai celemek pada saat mengolah makanan. Seharusnya pedagang menegur penjamahnya apabila tidak menggunakan celemek, menyediakan celemek, menyedikan celemek, apabila pemilik sudah menyediakan APD maka perlu dibuat peraturan untuk penjamah yang tidak menggunakan APD yang telah disediakan maka akan dikenakan hukuman atau sanki karena alat pelindung diri yang digunakan dapat menghindarkan penjamah dari bahaya atau kecelakaan yang sewaktu-waktu dapat terjadi pada saat bekerja. Selain untuk melindungi penjamah dari bahaya atau kecelakaan kerja, apabila tidak menggunakan APD dapat menumbulkan kontaminasi pada makanan sehingga dapat merugikan konsumen. d. Memakai Alat atau Alas Tangan (Sarung Tangan).

Dari 4 lokasi pada 4 pedagang sate ayam semua tidak memakai alat atau alas tangan (sarung tangan) pada saat mengolah makanan. Hal tersebut dapat mengakibatkan kontaminasi pada makanan akibat tangan yang kotor dan dapat menimbulkan penyakit akibat dari makanan yang terkontaminasi.

Menurut Keputusan Menteri Kesehatan RI No. 942/MENKES/SK/VII/2003 Tentang Persyaratan Higiene Sanitasi Makanan Jajanan, personal hygiene yang baik salah satunya memakai alat atau alas tangan (sarung tangan) ketika mengolah makanan. Apabila tidak menggunakan alat atau alas tangan (sarung tangan) pada saat menangani makanan penjamah harus mencuci tangan dengan air mengalir dan sabun setiap kali hendak menangani makanan, menjamah makanan harus memakai alat atau perlengkapan, atau dengan alas tangan. Seharusnya pemilik menyediakan alat atau alas tangan (sarung tangan), memberi teguran apabila penjamah dalam menangani makana tidak menggunakan alat atau alas tangan (sarung tangan).

Selain itu perlu dilakukan penyuluhan oleh petugas puskesmas atau dinas kesehatan setempat terhadap pedagang dan panjamah mengenai personal hygiene yang baik dan benar dalam bentuk poster atau stiker.

Berdasarkan tabel 4.2 perilaku penjamah dari 4 pedagang tersebut yang memenuhi syarat yaitu Mr. A dan B yaitu tidak sambil merokok, tidak sambil menggaruk anggota badan dan tidak batuk atau bersin dihadapan makanan. Hal tersebut sudah memenuhi syarat sesuai dengan Keputusan Menteri Kesehatan RI No. 942/MENKES/SK/VII/2003 Tentang Persyaratan Higiene Sanitasi Makanan Jajanan. Sedangkan pedagang Mr. C dan D masih tidak memenuhi syarat. Komponen yang belum memenuhi syarat yaitu :

a. a. Tidak Merokok Pada Saat Menjamah Makanan.

Pada penjamah Mr. C dan D masih merokok pada saat menjamah makanan, hal tersebut tidak sesuai dengan Keputusan Menteri Kesehatan RI No. 942/MENKES/SK/VII/2003 Tentang Persyaratan Higiene Sanitasi Makanan Jajanan. Apabila pada saat menjamah makanan penjamah merokok dikhawatirkan rokok tersebut akan mengkontaminasi makanan. Seharusnya penjamah tidak merokok pada saat menjamah makanan, menegur penjamah yang merokok pada saat sedang menjamah makanan dan melakukan penyuluhan baik dari puskesmas maupun dinas kesehatan setempat dengan cara pemasangan leaflet atau poster tentang perilaku penjamah yang benar. Penjamah juga seharusnya lebih memperhatikan perilaku mereka agar tidak menimbulkan kontaminasi pada makanan yang mereka olah sehingga dapat membahayakan konsumen. Untuk konsumen seharusnya dapat memilih sarana penjaja atau tempat penjualan sate yang bersih dan terjamin kualitasnya. 
b. Bahan Makanan

Tabel 3 Bahan Makanan 4 Pedagang Sate Ayam di Desa Pasir Lor Kecamatan Karanglewas Kabupaten Banyumas Tahun 2017

\begin{tabular}{|c|c|c|c|c|}
\hline No & Variabel & Kode & Skor & Kategori \\
\hline \multirow[t]{4}{*}{1} & Bahan & Mr. A & 6 & Memenuhi syarat \\
\hline & & Mr. B & 6 & Memenuhi syarat \\
\hline & & Mr. C & 6 & Memenuhi syarat \\
\hline & & Mr. D & 6 & Memenuhi syarat \\
\hline & $\%$ & \multicolumn{3}{|c|}{$\begin{array}{l}\text { Memenuhi syarat } 100 \% \\
\text { Tidak memenuhi syarat } 0 \%\end{array}$} \\
\hline
\end{tabular}

* Jumlah skor memenuhi syarat untuk variabel bahan makanan setiap pedagang yaitu 6 .

Dari ke 4 pedagang komponen bahan makanan telah memenuhi syarat semua, menurut Surya dkk (2010, hal. 9) daging ayam yang baik yaitu : daging segar, kulit ayam mengkilat dan kencang, berwarna segar, berbau khas bukan busuk, tidak memar (keunguan) dan tidak bengkak

\section{c.Sanitasi Alat}

Tabel 4 Sanitasi Alat 4 Pedagang Sate Ayam di Desa Pasir Lor Kecamatan Karanglewas Kabupaten Banyumas Tahun 2017

\begin{tabular}{|c|c|c|c|c|}
\hline No & Variabel & Kode & Skor & Kategori \\
\hline \multirow[t]{8}{*}{1} & \multirow{8}{*}{$\begin{array}{l}\text { Sanitasi } \\
\text { Alat }\end{array}$} & \multirow{2}{*}{ Mr. A } & \multirow[t]{2}{*}{2} & Tidak \\
\hline & & & & $\begin{array}{l}\text { Memenuhi } \\
\text { syarat }\end{array}$ \\
\hline & & \multirow[t]{2}{*}{ Mr. B } & \multirow[t]{2}{*}{3} & Tidak \\
\hline & & & & $\begin{array}{l}\text { Memenuhi } \\
\text { syarat }\end{array}$ \\
\hline & & \multirow[t]{2}{*}{ Mr. C } & \multirow[t]{2}{*}{3} & Tidak \\
\hline & & & & $\begin{array}{l}\text { Memenuhi } \\
\text { syarat }\end{array}$ \\
\hline & & \multirow[t]{2}{*}{ Mr. D } & \multirow[t]{2}{*}{3} & Tidak \\
\hline & & & & $\begin{array}{l}\text { Memenuhi } \\
\text { syarat }\end{array}$ \\
\hline & $\%$ & Meme & is & $0 \%$ \\
\hline
\end{tabular}

* Jumlah skor memenuhi syarat untuk variabel sanitasi alat setiap pedagang yaitu 4 .

Berdasarkan tabel 4 sanitasi alat dari 4 pedagang tersebut semua tidak memenuhi syarat, hal ini disebabkan karena masih terdapat komponen yang belum memenuhi syarat dari 4 pedagang tersebut komponen sanitasi alat yang belum memenuhi syarat yaitu:

a. Alat dikeringkan dengan Alat Pengering atau Lap Bersih.

Pada sanitasi alat Mr. A tidak mengeringkan peralatan dengan alat pengering atau lap. Menurut Keputusan Menteri Kesehatan Republik Indonesia Nomor 942/MENKES/SK/VII/2003 Tentang Persyaratan Higiene Sanitasi Makanan Jajanan syarat sanitasi peralatan salah satunya yaitu peralatan dikeringkan dengan alat pengering atau lap bersih. Mengeringkan alat dengan lap atau alat pengering bertujuan untuk menghindari berkaratnya peralatan yang terbuat dari besi, semua peralatan yang kontak dengan makanan harus disimpan dalam keadaan kering dan bersih agar tidak lembab dan menjadi tempat berkembangnya bakteri. Kain lap yang digunakan untuk mengeringkan alat harus bersih jika sudah mulai kotor dan basah maka kain lap diganti dengan kain yang bersih dan kering atau dengan menjemur peralatan yang sudah dicuci dibawah sinar matahari.

Selain itu perlu dilakukan penyuluhan oleh petugas puskesmas atau dinas kesehatan setempat terhadap pedagang mengenai pentingnya mengeringkan peralatan agar alat bebas dari kontaminasi.

b. Tempat Penyimpanan Alat Bebas dari Pencemar.

Pada ke 4 lokasi penelitian tempat penyimpanan alat semuanya masih dapat tercemar. Menurut Keputusan Menteri Kesehatan Republik Indonesia Nomor 942/MENKES/SK/VII/2003 Tentang Persyaratan Higiene Sanitasi Makanan Jajanan syarat sanitasi peralatan salah satunya yaitu disimpan pada tempat yang bebas dari pencemar. Tempat penyimpanan harus bebas dari pencemar seperti debu, serangga dan tikus, apabila menyimpan peralatan pada tempat yang tidak bebas dari pencemar maka alat akan terkontaminasi dan makanan yang diolah dan disajikan dengan alat tersebut dapat terkontaminasi. Seharusnya pemilik penyimpan peralatan pada tempat penyimpanan yang bebas pencemar seperti tempat penyimpanan tidak lembab, terlindung dari sumber kontaminasi atau pengotor dan binatang perusak.

Selain itu perlu dilakukan penyuluhan oleh petugas puskesmas atau dinas kesehatan setempat terhadap pedagang mengenai sanitasi peralatan, cara penyimpanan peralatan yang baik dan benar agar pedagang lebih tau tentang pemeliharaan dan kebersihan alat agar terhindar dari kontaminasi.

\section{d. Sanitasi Tempat Pengolahan}

Tabel 5 Sanitasi Dapur dan Sarana Penjaja 4 Pedagang Sate Ayam di Desa Pasir Lor Kecamatan Karanglewas Kabupaten Banyumas Tahun 2017

\begin{tabular}{|c|c|c|c|c|}
\hline No & Variabel & Kode & Skor & Kategori \\
\hline \multirow[t]{8}{*}{1} & \multirow[t]{8}{*}{ Dapur } & \multirow[t]{2}{*}{ Mr. A } & \multirow[t]{2}{*}{5} & Tidak \\
\hline & & & & $\begin{array}{l}\text { Memenuhi } \\
\text { syarat }\end{array}$ \\
\hline & & \multirow[t]{2}{*}{ Mr. B } & \multirow[t]{2}{*}{5} & Tidak \\
\hline & & & & $\begin{array}{l}\text { Memenuhi } \\
\text { syarat }\end{array}$ \\
\hline & & \multirow[t]{2}{*}{ Mr. C } & \multirow[t]{2}{*}{6} & Tidak \\
\hline & & & & $\begin{array}{l}\text { Memenuhi } \\
\text { syarat }\end{array}$ \\
\hline & & \multirow[t]{2}{*}{ Mr. D } & \multirow[t]{2}{*}{5} & Tidak \\
\hline & & & & $\begin{array}{l}\text { Memenuhi } \\
\text { syarat }\end{array}$ \\
\hline & $\%$ & \multicolumn{3}{|c|}{$\begin{array}{l}\text { Memenuhi syarat } 0 \% \\
\text { Tidak memenuhi syarat } 100 \%\end{array}$} \\
\hline
\end{tabular}




\begin{tabular}{|c|c|c|c|c|}
\hline No & Variabel & Kode & Skor & Katagori \\
\hline \multirow[t]{7}{*}{2} & \multirow{6}{*}{$\begin{array}{l}\text { Sarana } \\
\text { Penjaja }\end{array}$} & \multirow[t]{2}{*}{ Mr. A } & \multirow[t]{2}{*}{6} & Tidak \\
\hline & & & & $\begin{array}{l}\text { Memenuhi } \\
\text { syarat }\end{array}$ \\
\hline & & \multirow[t]{2}{*}{ Mr. B } & \multirow[t]{2}{*}{6} & Tidak \\
\hline & & & & $\begin{array}{l}\text { Memenuhi } \\
\text { syarat }\end{array}$ \\
\hline & & Mr. C & 8 & $\begin{array}{l}\text { Memenuhi } \\
\text { syarat }\end{array}$ \\
\hline & & Mr. D & 8 & $\begin{array}{l}\text { Memenuhi } \\
\text { syarat }\end{array}$ \\
\hline & $\%$ & \multicolumn{3}{|c|}{$\begin{array}{l}\text { Memenuhi syarat } 50 \% \\
\text { Tidak memenuhi syarat } 50 \%\end{array}$} \\
\hline
\end{tabular}

* Jumlah skor memenuhi syarat untuk variabel dapur setiap pedagang yaitu 7. dan jumlah skor untuk sarana penjaja yaitu 8 .

a. Dapur

Menurut tabel 5 sanitasi dapur mulai dari adanya ventilasi pada dapur, lantai, dinding, meja peracik tahan gores, cerobong asap, dan bebas lalat dan tikus dari 4 pedagang tersebut semuanya tidak memenuhi syarat. Komponen yang belum memenuhi syarat yaitu:

1) Meja Peracik Tahan Gores

Untuk Mr. A, B dan D meja peracik tidak tahan gores. Menurut Direktorat Jenderal PP \& PL KEMENKES RI (2010, h.119) persyaratan tempat pengolahan makanan salah satunya yaitu permukaan meja peracik tahan gores. Apabila permukaan meja peracik terbuat dari bahan yang tidak tahan gores dikhawatirkan pada saat makanan diracik meja tersebut dapat mengkontaminasi makanan tersebut. Seharusnya meja peracik dibuat dengan bahan tahan gores agar tidak mencemari makanan.

2) Dapur Bebas dari Lalat dan Tikus

Dari ke 4 pedagang tersebut dapur mereka tidak bebas dari lalat dan tikus. Menurut Direktorat Jenderal PP \& PL KEMENKES RI (2010, h.119) persyaratan tempat pengolahan makanan salah satunya harus bebas dari lalat dan tikus. Dapur yang tidak terbebas dari lalat dan tikus dapat membahayakan konsumen melalui kontaminasi makanan. Lalat dan tikus dapat menularkan penyakit apabila makanan dan peralatan yang ada didapur terkontaminasi oleh lalat dan tikus. Cara untuk menghindari lalat dan tikus diantaranya yaitu:

a. Dapur selalu dibersihkan sebelum dan sesudah digunakan

b. Tersedinya tempat sampah yang tertutup agar tidak menimbulkan datangnya lalat dan tikus

c. Saluran pembuangan limbah dapur harus tertutup dan tidak rusak agar air limbah lancar dan tidak menimbulkan bau yang akan menimbulkan datangnya lalat dan tikus.

d. Tidak ada tumbukan peralatan atau barang dan bahan makanan yang dapat dijadikan sebagai sarang tikus.

Selain itu pengetahuan dan perilaku pedagang dan penjamah tentang syarat tempat pengolahan perlu ditingkatkan agar mereka dapat mengetahui syarat dapur yang baik dan perilaku yang baik dalam mengolah makanan. Hal tersebut dapat dilakukan dengan cara penyuluhan oleh pihak puskesmas atau melibatkan dinas kesehatan setempat. Komponen yang belum memenuhi syarat seperti permukaan meja peracik yang tidak tahan gores dan dapur tidak bebas dari lalat dan tikus seharusnya diperbaiki seperti melapisi meja peracik dengan bahan anti gores, rajin membersihkan dapur seperti menyapu, mengepel dan membersihkan sampah agar dapur selalu bersih dan tidak menjadi tempat bersarang tikus dan lalat,melakukan pengendalian terhadap serangga da tikus secara berkala dengan mengenali tanda-tanda keberadaan tikus seperti adanya kotoran tikus, jalan tikus, bekas gigitan tikus, bau atau urine tikus da terdapat bangkai tikus. Hal ini dilakukan agar terciptanya tempat pengolahan makanan yang baik sehingga kualitas makanan tetap terjaga dan bebas dari kontaminasi.

b. Sarana Penjaja

Menurut tabel 5 sanitasi sarana penjaja mulai dari konstruksi sarana penjaja dapat melindungi makanan dari pencemar, mudah dibersihkan, tersedia tempat air, tersedia tempat penyimpanan bahan makanan, tersedia tempat penyimpanan alat, tersedia tempat cuci tangan, tersedia tempat cuci alat da tersedia tempat sampah dari 4 pedagang tersebut 2 memenuhi syarat dan 2 pedagang tidak memenuhi syarat. Komponen yang belum memenuhi syarat pada sarana penjaja yaitu:

1) Tersedianya Tempat Cuci Tangan

Pada lokasi penelitian Mr. A dan B yaitu tidak tersedia tempat mencuci tangan. Menurut Keputusan Menteri Kesehatan Republik Indonesia Nomor 942/MENKES/SK/VII/2003 Tentang Persyaratan Higiene Sanitasi Makanan Jajanan persyaratan sarana penjaja salah satunya adalah adanya tempat cuci tangan. Tempat mencuci tangan sangat penting pada sarana penjaja karena setiap penjamah sebelum menangani makanan dan konsumen sebelum menyantap makanan seharusnya mencuci tangan terlebih dahulu untuk menghindari adanya kontaminasi pada makanan akibat dari tangan yang kurang bersih dan dapat meyebabkan penyakit seperti diare. Seharusnya pedagang menyediakan tempat cuci tangan pada sarana penjaja agar sesuai dengan persyaratan sarana penjaja yang memenuhi syarat.

2) Tersedianya Tempat Cuci Alat

Pada lokasi penelitian Mr. A dan B yaitu tidak tersedia tempat untuk mencuci alat. Menurut Keputusan Menteri Kesehatan Republik Indonesia Nomor 942/MENKES/SK/VII/2003 Tentang Persyaratan Higiene Sanitasi Makanan Jajanan persyaratan sarana penjaja salah satunya adalah adanya tempat cuci alat. Jika tidak terdapat tempat mencuci peralatan maka dikhawatirkan sisa-sisa bahan dan makanan yang ada pada peralatan akan mengundang serangga atau lalat yang dapat mengkontaminasi bahan makana, peralatan dan makanan. Seharusnya pedagang menyediakan tempat mencuci peralatan dengan menggunakan air mengalir atau menggunakan 3 bak. 


\section{h. Penyajian Makanan}

Tabel 9 Cara Penyajian Makanan 4 Pedagang Sate Ayam di Desa Pasir Lor Kecamatan Karanglewas Kabupaten Banyumas Tahun 2017

\begin{tabular}{|c|c|c|c|c|}
\hline No & Variabel & Kode & Skor & Kategori \\
\hline \multirow[t]{4}{*}{1} & $\begin{array}{l}\text { Penyajian } \\
\text { Makanan }\end{array}$ & Mr. A & 6 & $\begin{array}{l}\text { Memenuhi } \\
\text { syarat }\end{array}$ \\
\hline & & Mr. B & 6 & $\begin{array}{l}\text { Memenuhi } \\
\text { syarat }\end{array}$ \\
\hline & & Mr. C & 6 & $\begin{array}{l}\text { Memenuhi } \\
\text { syarat }\end{array}$ \\
\hline & & Mr. D & 6 & $\begin{array}{l}\text { Memenuhi } \\
\text { syarat }\end{array}$ \\
\hline & $\%$ & $\begin{array}{l}\text { Memt } \\
\text { Tidak }\end{array}$ & & $\begin{array}{c}100 \% \\
\text { yarat } 0 \% \\
\end{array}$ \\
\hline
\end{tabular}

*Jumlah skor memenuhi syarat untuk variabel penyajian makanan setiap pedagang yaitu 6 .

Berdasarkan tabel 9 cara penyajian makanan dari 4 pedagang tersebut semua memenuhi syarat. Hal yang memenuhi syarat penyajian makanan menurut Keputusan Menteri Kesehatan RI No. 942/MENKES/SK/VII Tahun 2003 Tentang Pedoman Persyaratan Hygiene Sanitasi Makanan Jajanan yaitu makanan disajikan dengan tempat dan alat penyajian yang bersih, terbungkus rapat, pembungkus dlam keadaan bersih, pembungkus tidak mencemari makanan dan pembungkus tidak ditiup.

Makanan yang sudah diolah dengan baik dan benar apabila disajikan dengan cara yang tidak baik dan benar sesuai dnegan persyaratan maka kemungkinan akan tetap tercemar. Seharusnya pedagang dan penjamah tetap memeperhatiakan cara penyajian yang baik dan benar sesuai dengan persyaratan agar makanan yang sudah diolah dengan baik dan benar tidak tercemar pada waktu tahap penyajian.

2. Keberadaan Bakteri Salmonella sp

Tabel 10 Hasil Pemeriksaan Sate Ayam Mentah Pada Pedagang Sate Ayam di Desa Pasir Lor Kecamatan Karanglewas Kabupaten Banyumas Tahun 2017

\begin{tabular}{llll} 
No & $\begin{array}{l}\text { Kode } \\
\text { sampel }\end{array}$ & $\begin{array}{l}\text { Hasil } \\
\text { Pemeriksaan }\end{array}$ & Standar \\
\hline 1. & Mr. A1 & Positif & Negatif/25 gr \\
2. & Mr. B1 & Negatif & \\
3. & Mr. C1 & Positif & \\
4. & Mr. D1 & Positif &
\end{tabular}

* Peraturan Badan Pengawas Obat dan Makanan Republik Indonesia Nomor HK.00.06.1.52.4011 tentang Penetapan Batas Maksimum Cemaran Mikroba dan Kimia dalam Makanan, bakteri Salmonella sp pada daging ayam atau olahan adalah negatif/25 gram.
Tabel 11 Hasil Pemeriksaan Sate Ayam Matang Pada Pedagang Sate Ayam di Desa Pasir Lor Kecamatan Karanglewas Kabupaten Banyumas Tahun 2017

\begin{tabular}{llll}
\hline No & $\begin{array}{l}\text { Kode } \\
\text { sampel }\end{array}$ & $\begin{array}{l}\text { Hasil } \\
\text { Pemeriksaan }\end{array}$ & Standar \\
\hline 1. & Mr. A2 & Negatif & Negatif/25 gr \\
2. & Mr. B2 & Negatif & \\
3. & Mr. C2 & Negatif & \\
4. & Mr. D2 & Negatif &
\end{tabular}

* Peraturan Badan Pengawas Obat dan Makanan Republik Indonesia Nomor HK.00.06.1.52.4011 tentang Penetapan Batas Maksimum Cemaran Mikroba dan Kimia dalam Makanan, bakteri Salmonella sp pada daging ayam atau olahan adalah negatif/25 gram.

4.Kesimpulan: Dari hasil pemeriksaan yang telah dilakukan oleh peneliti di 4 pedagang sate ayam di Desa Pasir Lor Kecamatan Karanglewas Kabupaten Banyumas, dapat diperoleh simpulan sebagai berikut:

\section{Hygiene Sanitasi Pengolahan Sate Ayam \\ a. Penjamah}

Berdasarkan hasil observasi yang telah dilakukan oleh peneliti di 4 lokasi penelitian (A-D), aspek penjamah mulai dari personal hygiene dan perilaku penjamah. Komponen yang menyebabkan personal hygiene penjamah tidak memenuhi syarat yaitu kuku tidak dalam keadaan bersih, tidak memakai celemek, tidak mencuci tangan setiap akan menagani makanan, tidak memakai alat/alas tangan dan perilaku penjamah yang masih merokok pada saat menangani makanan. Dari ke 4 pedagang tersebut untuk personal hygiene semua tidak memenuhi syarat dan untuk perilaku penjamah 2 memenuhi syarat.

\section{b. Bahan Makanan}

Berdasarkan hasil observasi yang dilakukan oleh peneliti di 4 lokasi penelitian (A-D), aspek bahan makanan utama (daging ayam) dikategorikan memenuhi syarat semua pada 4 pedagang.

\section{c. Sanitasi Alat}

Berdasarkan hasil observasi yang dilakukan peneliti di 4 lokasi penelitian (A-D), aspek sanitasi alat dikategorikan tidak memenuhi syarat semua, hal ini disebabkan masih adanya komponen yang belum memenuhi syarat seperti tidak mengeringkan alat dengan lap bersih atau alat pengering dan tempat penyimpanan alat masih dapat tercemar.

\section{d. Sanitasi Tempat Pengolahan}

Berdasarkan hasil observasi yang telah dilakukan oleh peneliti di 4 lokasi penelitian (A-D), aspek sanitasi tempat pengolahan mulai dari dapur dan sarana penjaja. Komponen yang menyebabkan sanitasi tempat pengolajan (dapur) tidak memenuhi syarat yaitu permukaan meja peracik tidak tahan gores dan dapur tidak bebas lalat dan tikus. Untuk sara penjaja dari 4 pedagang 2 memenuhi syarat (C-D) dan 2 tidak memenuhi syarat (A-B) . Komponen yang menyebabkan tidak memenuhi syarat tidak adanya tempat cuci tangan dan tempat cuci alat. 


\section{e. Cara Pemilihan Bahan Makanan}

Berdasarkan hasil observasi yang elah dilakukan oleh peneiti di 4 lokasi penelitian (A-D) dalam cara pemilihan bahan makanan diperoleh hasil memenuhi syarat untuk ke 4 pedagang sate ayam tersebut.

\section{f. Penyimpanan Bahan Makanan}

Berdasarkan hasil observasi yang elah dilakukan oleh peneiti di 4 lokasi penelitian (A-D) dalam penyimpanan bahan makanan diperoleh hasil tidak memenuhi syarat untuk ke 4 pedagang sate ayam tersebut.

\section{g. Pengolahan Makanan}

Berdasarkan hasil observasi yang elah dilakukan oleh peneiti di 4 lokasi penelitian (A-D) dalam pengolahan makanan diperoleh hasil memenuhi syarat untuk ke 4 pedagang sate ayam tersebut.

\section{h. Penyajian Makanan}

Berdasarkan hasil observasi yang elah dilakukan oleh peneiti di 4 lokasi penelitian (A-D) dalam penyajian makanan diperoleh hasil memenuhi syarat untuk ke 4 pedagang sate ayam tersebut.

\section{Keberadaan Salmonella sp Pada Sate Ayam}

Hasil pemeriksaan pada sampel sate ayam sebelum dan sesudah dipanggang dari 4 pedagang sebagai berikut:

a. Sebelum dipanggang 3 positif bakteri Salmonella $s p$

b. Sesudah dipanggang dari ke 4 pedagang semuanya negatif bakteri Salmonella sp (tidak ada Salmonella)

Ucapan Terimakasih: Dalam penyelesaian karya tulis ilmiah ini, penulis banyak mendapatkan bantuan baik materil maupun moril dari berbagai pihak, untuk itu penulis mengucapkan terimakasih kepada :

1. Bapak Sugiyanto, S.Pd, M.App.Sc. selaku Direktur Politeknik Kesehatan Kementerian Kesehatan Semarang.

2. Bapak Asep Tata Gunawan, SKM, M.Kes, selaku Ketua Jurusan Kesehatan Lingkungan Purwokerto dan pembimbing karya tulis ilmiah

3. Bapak Suparmin, SST, M.Kes, selaku Ketua Program Studi DIII Kesehatan Lingkungan

4. Bapak Marsum, BE, S.Pd, M.HP, selaku Dosen pembimbing akademik

5. Bapak Ibu dosen yang telah membantu dalam penyusunan karya tulis ilmiah

6. Alm.mamah yang selalu mengingatkan penulis untuk tetap semangat dan berdoa

7. Bapak dan Ibu yang senantiasa memberikan dukungan moril dan material.

8. Mas, mba dan dua ade kecil yang selalu memberikan semangat

9. Teman-teman yang selalu memberikan semangat dan dukungan

10. Reguler A angkatan 2014 yang telah menjadi bagian dari 3 tahun cerita penulis di JKL Purwokerto

11. Semua pihak terkait yang telah membantu menyelesaikan proposal penilitian karya tulis ilmiah.
Daftar Pustaka

Anwar, Soedarso, dkk, 1987, Sanitasi Makanan dan Minuman pada Institusi Pendidikan Tenaga Sanitasi, Jakarta: Departemen Kesehatan RepublikIndonesia.

Arisman, 2009, Keracunan Makanan:Buku Ajar Ilmu Gizi, Jakarta: EGC

Asep, Dwi, Mawaddah, 2015, Modul Praktek Laboratorium PMM-A, Poltekkes Kemenkes Semarang D3 Kesehatan Lingkungan.

Budiman Chandra, 2007, Pengantar Kesehatan Lingkungan, Jakarta: Penerbit Buku Kedokteran EGC

Damaris Adolfina Tefa, 2006, Studi Kandungan Salmonella Pada Daging Ayam Segar Yang Dijual di Pasar Sarimulyo Purwoketo Timur Tahun 2006, Karya Tulis Ilmiah pada Jurusan Kesehatan Lingkungan Poltekkkes Kemenkes Semarang

Depkes RI, 2000, Prinsip-Prinsip Hygiene Sanitasi Makanan, Jakarta: Departemen Kesehatan RI

Dinas Kesehatan Provinsi Jawa Tengah, 2004, "Bab IV : Pencapaian program kesehatan menuju jawa tengah sehat”, Jurnal Dinas Kesehatan Provinsi JawaTengah,http://www.dinkesjatengprov.go.id /dokumen/profil/profile 2004/bab4.htm, 25 November 2016

Direktorat Jenderal PP \& PL KEMENTERIAN KESEHATAN RI, 2010, Kumpulan Modul Kursus Hygiene Sanitasi Makanan \& Minuman, Jakarta: Depkes RI

Dir Jen POM No.HK.00.06.1.52.4011 Tahun 2009 tentang penetapan batas maksimum cemaran mikroba dan kimia dalam makanan

KEPMENKES RI No.942/MENKES/SK/VII/2003 tentang Persyaratan Higiene Sanitasi Makanan Jajanan

KEPMENKES RI No.1098/Menkes/Sk/VII/2003 tentang Persyaratan Hygiene Sanitasi Rumah Makan dan Restoran

Koes Irianto, 2006, Mikrobiologi Menguak Dunia Mikroorganisme Jilid 2, Bandung: Yrama Widya

Lukman Saksono, 1986, Pengantar Sanitasi Makanan, Bandung: Alumni

M.J Pelczar Jr dan E.C.S Chan, 1988, Dasar-Dasar Mikrobiologi, Jakarta: Universitas Indonesia

M.juni Mirzal Al furqon, 2012, Makanan dan Salmonella sp, Jakarta: Transmedia Pustaka

Pengertian sate ayam, http://kbbi.web.id/sate , (24 Januari 2017)

PERMENKES RI No.1096/MENKES/PER/VI/2011 tentang Persyaratan Hygiene Sanitasi Jasaboga, Jakarta

Regional Kompas , 2012, "40 Warga Pasaman Barat KeracunanSate"http://regional.kompas.com/rea d/2012/12/13/08505129/mediasiber.html (Oktober 2016) 
https://id.wikibooks.org/wiki/Resep:Sate_ayam (31 oktober 2016)

Riau Pos, 2014, "5 Warga Rokan Hulu Keracunan Sate”http://m.riaupos.co/48216-berita-5-wargarokan-hulu-keracunan-sate.html, (31 Oktober 2016)

Standar Nasional Indonesia 7388:2009 tentang Batas Maksimum Cemaran Mikroba dalam Pangan, Jakarta

Surya sugandi \&lucia priandini, 2010, Cerdas Untuk Sehat, Rahasia Hidup Sehat Tanpa Dokter, Jakarta: transmedia pustaka

Tri Cahyono, 2004, Pedoman Penulisan Proposal dan Karya Tulis Ilmiah/Skripsi Edisi revisi ketiga, Purwokerto, Kementerian Kesehatan RI Politeknik Kesehatan Depkes Semarang Jurusan Kesehatan Lingkungan

Undang - Undang Republik Indonesia No. 36 Tahun 2009 Tentang Kesehatan

WHO, 2002, Buku Penyakit Bawaan Makanan Fokus Pendidikan Kesehatan, Jakarta:Buku Kedokteran EGC 